\title{
Hexane extract of aged black garlic reduces cell proliferation and attenuates the expression of ICAM-1 and VCAM-1 in TNF- $\alpha$-activated human endometrial stromal cells
}

\author{
KI-HYUNG KIM ${ }^{1,2^{*}}$, JIN KYEONG PARK ${ }^{3,4 *}$, YOUNG-WHAN CHOI ${ }^{5}$, YOUN-HAN KIM ${ }^{5}$, EUN NA LEE ${ }^{3}$, \\ JA-RANG LEE ${ }^{6}$, HEUI-SOO KIM ${ }^{6}$, SUN-YONG BAEK ${ }^{3}$, BONG-SEON KIM ${ }^{3}$, KYU-SUP LEE ${ }^{1,2}$ and SIK YOON ${ }^{2-4}$ \\ ${ }^{1}$ Department of Obstetrics and Gynecology, Pusan National University School of Medicine, Busan 602-739; \\ ${ }^{2}$ Medical Research Institute, Pusan National University Hospital, Busan 602-739; ${ }^{3}$ Department of Anatomy and \\ ${ }^{4}$ Medical Research Institute, Pusan National University School of Medicine, Yangsan 626-870; \\ ${ }^{5}$ Department of Horticultural Bioscience, College of Natural Resources and Life Science, \\ Pusan National University, Miryang 627-706; ${ }^{6}$ Department of Biological Sciences, \\ College of Natural Sciences, Pusan National University, Busan 609-735, Republic of Korea
}

Received February 14, 2013; Accepted April 12, 2013

DOI: $10.3892 /$ ijmm.2013.1362

\begin{abstract}
Increasing evidence indicates the potentially crucial roles of intercellular adhesion molecule-1 (ICAM-1) and vascular cell adhesion molecule-1 (VCAM-1) in the pathological process underlying endometriosis. The present study aimed to investigate the effects of a hexane extract of aged black garlic (HEABG) on the proliferation and expression of ICAM-1 and VCAM-1 in tumor necrosis factor- $\alpha$ (TNF- $\alpha$ )activated human endometrial stromal cells (HESCs) isolated from patients with endometriosis. HESCs were isolated from endometriotic tissues obtained from women with advanced endometriosis who underwent laparoscopic surgery for ovarian endometrioma $(n=18)$. Cell proliferation and cell cycle analysis were assessed by WST-1 assay and flow cytometry, respectively. The expression of ICAM-1 and VCAM-1 was measured by flow cytometry, immunofluorescence staining, immunoblotting and quantitative reverse transcriptase-PCR. The secretion of interleukin-6 (IL-6) was determined by enzyme-linked immunosorbent assay (ELISA). The activation of nuclear factor- $\mathrm{\kappa B}(\mathrm{NF}-\mathrm{\kappa B})$ and activator protein-1 (AP-1) was detected by electrophoretic mobility shift assay (EMSA) and the activation of c-Jun N-terminal kinase (JNK), extra-
\end{abstract}

Correspondence to: Professor Sik Yoon, Department of Anatomy, Pusan National University School of Medicine, 49 Busandaehak-ro, Mulgeum-eup, Yangsan 626-870, Republic of Korea

E-mail: sikyoon@pusan.ac.kr

*Contributed equally

Key words: activator protein-1, aged black garlic, endometriosis, intercellular adhesion molecule-1, nuclear factor- $\kappa \mathrm{B}$, vascular cell adhesion molecule-1 cellular signal-regulated kinase (ERK) and p38 MAPK was analyzed by immunoblotting. Cell proliferation and cell cycle progression were significantly suppressed by HEABG in the TNF- $\alpha$-induced HESCs through the inhibition of the ERK and JNK signaling pathways. Remarkably, the treatment of the HESCs with HEABG potently suppressed the TNF- $\alpha$-induced ICAM-1 and VCAM-1 transcript and protein expression by inhibiting the activation of NF- $\mathrm{KB}$ and AP-1 transcription factors. Our results suggest that HEABG may be effective in the prevention and treatment of endometriosis in humans.

\section{Introduction}

Endometriosis is a benign, estrogen-dependent, gynecological disorder that is defined as the presence of endometrial glands and stroma outside the uterine cavity. Women with endometriosis may present with chronic pelvic pain, dysmenorrhea, dyspareunia and/or infertility. Retrograde menstruation, peritoneal adhesion and outgrowth of endometrial tissue are major factors in the pathogenesis of endometriosis according to Sampson's classic implantation theory (1). However, the stimuli promoting the attachment and outgrowth of endometrial cells in the peritoneal cavity have remained largely unknown. Among many factors suggested to be involved in the pathogenesis of endometriosis, immunological and inflammatory responses have been suggested to play crucial roles in the development and progression of endometriosis, and thus the disease may be considered an immune-related chronic inflammatory disease $(2,3)$.

Cell adhesion molecules mediate essential cell-cell interactions and play an important role in cell differentiation, the organization of the extracellular matrix and in the recruitment and aggregation of leukocytes from the circulation. Intercellular adhesion molecule-1 (ICAM-1, CD54) mediates various biological processes, including adhesive interactions with integrins, leukocyte extravasation and lymphocyte-mediated 
cytotoxicity (4). The expression of ICAM-1, which is upregulated in response to a number of inflammatory mediators, such as tumor necrosis factor (TNF)- $\alpha$, is associated with a variety of inflammatory diseases and conditions (4). Similar to ICAM-1, vascular cell adhesion molecule-1 (VCAM-1, CD106) also has a well-characterized role in immunological responses in humans. VCAM-1 plays an important role in mediating mononuclear leukocyte-selective adhesion to vascular endothelial cells, preparing them for transendothelial migration into inflammatory foci. The upregulation of VCAM-1 in endothelial cells is induced by pro-inflammatory cytokines, such as TNF- $\alpha$, interleukin (IL)-1 $\beta$ and interferon (IFN)- $\gamma$ (5). A growing body of evidence suggests that these critical cell adhesion molecules in various immune and inflammatory responses also play pivotal roles in the physiology and pathophysiology of the human endometrium. ICAM-1 is expressed in a regulated pattern by endometrial stromal cells during the menstrual cycle (6). ICAM-1 is expressed in cultured human endometrial stromal cells (HESCs), as well as in endometrial stromal cells in the human endometrium in situ $(7,8)$. Furthermore, in patients with endometriosis, ICAM-1 is more strongly expressed in ectopic endometrial stromal cells than in eutopic endometrial stromal cells (9), and the elevated expression of ICAM-1 is induced in endometrial stromal cells by pro-inflammatory cytokines, such as IFN- $\gamma$ (10). These data suggest that crosstalk may occur between endometrial stromal cells and leukocytes in the endometrium and peritoneal fluid via ICAM-1 and its receptors, contributing to the pathological processes of endometriosis. In addition to ICAM-1, VCAM-1 is expressed in HESCs, but little is known about the expression and role of VCAM-1 in endometriosis (11).

TNF- $\alpha$, a pleiotropic pro-inflammatory cytokine, is regarded as an important regulatory molecule in eliciting inflammatory immune responses in endometriosis, and its abnormal production may contribute to the pathophysiology of endometriosis, including cell proliferation and adhesion $(1,12)$. The nuclear factor- $\kappa \mathrm{B}(\mathrm{NF}-\kappa \mathrm{B})$ and activator protein-1 (AP-1) transcription factors play key roles in immune and inflammatory responses, and modulate cell proliferation, apoptosis, adhesion, invasion and angiogenesis in several cell types, including endometrial cells $(13,14)$. The activation of $\mathrm{NF}-\kappa \mathrm{B}$ has been implicated in the early development of endometriotic lesions in vivo (13). In particular, AP-1 and NF- $\mathrm{BB}$ are the principal transcription factors that regulate the expression of adhesion molecules, such as ICAM-1 and VCAM-1 (15).

Garlic (Allium sativum; A. Savitum) has long been cultivated as a food and used as a home remedy in Asia. Garlic derivatives have important pharmacological properties, such as anti-inflammatory, anti-microbial, anti-thrombotic, anti-hypertensive, anti-hyperlipidemic, anti-hyperglycemic, immune system enhancement and anti-tumor properties (16). These findings indicate that garlic extracts are clinically effective for the treatment of diverse human diseases. Aged black garlic, intended as a healthy dietary supplement, is a type of fermented garlic used as a food ingredient in Korea, Thailand and Japan. Its unique qualities are the result of the fermentation of whole garlic bulbs under high temperatures for several months. Upon fermentation, regular garlic, which has a strong flavor and pungent odor, turns into soft, sweet, odorless and black garlic.
The aim of the present study was to investigate the effects of a hexane extract of aged black garlic (HEABG) on the cell proliferation and expression of ICAM-1 and VCAM-1 in TNF- $\alpha$-activated HESCs isolated from patients with endometriosis.

\section{Materials and methods}

Plant materials. Garlic (A. sativum L.) specimens were collected in January 2008 from Changnyeong, Korea. Aged black garlic was manufactured by Newgreen Food Co. (Changnyeong, Korea) by incubating raw garlic at $75^{\circ} \mathrm{C}$ and $70 \%$ relative humidity for 2 weeks. A voucher specimen (accession no. NBG-PRDR-11) was deposited in the Plant Drug Research Laboratory of Pusan National University (Miryang, Korea).

Preparation of HEABG from aged black garlic. Aged black garlic extracts $(500 \mathrm{ml})$ were purchased directly from Newgreen Food Co. in January 2009. The aged black garlic extracts were successively partitioned with hexane, chloroform and n-butanol. The upper suspension layer was filtered and evaporated under reduced pressure at $45^{\circ} \mathrm{C}$ and then lyophilized. A yellow, oily residue of hexane extract $(17.6 \mathrm{mg})$ was obtained. The remaining aqueous layer was then sequentially partitioned with chloroform and n-butanol to yield chloroform (348 mg) and n-butanol fractions (11.53 g), respectively. The hexane fraction was used in this study. Hexane, chloroform, ethyl acetate, n-butanol and methanol were purchased from Fisher Scientific, Ltd. (Pittsburgh, PA, USA).

Subjects. Eighteen women (aged 25-45 years; mean age, $35.44 \pm 5.99$ years) with advanced endometriosis (III/IV) were enrolled in this study (Table I). These women, who were treated for dysmenorrhea, pelvic pain or leiomyoma, were found to have endometriosis during laparoscopy, had no endometrial hyperplasia or neoplasia, and had not received anti-inflammatory nor any other hormonal treatment in the 3 months prior to surgery (Table I). The menstrual cycle phase of each patient enrolled in this study was recorded (Table I). Ovarian endometrioma specimens were obtained by performing laparoscopic surgery (Table I). Ovarian endometrioma capsules were removed from the normal ovarian cortex for pathologic examination and further culture preparation. Endometriotic biopsy samples were immediately placed in sterile Hanks' balanced salt solution (HBSS) containing $100 \mathrm{U} / \mathrm{ml}$ penicillin, $100 \mathrm{mg} / \mathrm{ml}$ streptomycin and $0.25 \mathrm{mg} / \mathrm{ml}$ amphotericin and maintained at $4^{\circ} \mathrm{C}$. The diagnosis and staging of endometriosis in all cases was performed according to the revised American Society for Reproductive Medicine classification system (17) and confirmed by histopathological analysis. Written informed consent was obtained from all of the patients, and the study protocol was approved by the Institutional Review Board at Pusan National University Hospital.

Cell culture system. Immediately after the tissues were transported to the laboratory, cell culture was performed in Dulbecco's modified Eagle's medium (DMEM) containing 10\% fetal bovine serum (FBS). Chemicals and culture media were purchased from Life Technologies (Gaithersburg, MD, USA), 
Table I. Clinical characteristics of patients, sources of endometriotic tissue biopsy samples, laparoscopic findings and clinical parameters.

\begin{tabular}{|c|c|c|c|c|c|c|}
\hline $\begin{array}{l}\text { Patient } \\
\text { No. }\end{array}$ & $\begin{array}{c}\text { Age } \\
\text { (years) }\end{array}$ & $\begin{array}{l}\text { Cell cycle } \\
\text { phase }\end{array}$ & $\begin{array}{c}\text { ASRM } \\
\text { stage of } \\
\text { endometriosis }\end{array}$ & $\begin{array}{c}\text { Location of } \\
\text { endometriotic } \\
\text { tissue }\end{array}$ & Clinical parameters & Type of experiment \\
\hline 1 & 42 & Proliferative & IV & Both ovaries & Dysmenorrhea & Cytotoxicity, proliferation \\
\hline 2 & 38 & Secretory & IV & Both ovaries & Menorrhagia, dysmenorrhea & Cytotoxicity, qRT-PCR \\
\hline 3 & 44 & Proliferative & IV & Right ovary & $\begin{array}{l}\text { Presence of leiomyoma, } \\
\text { intermittent pelvic pain }\end{array}$ & Proliferation, FACS \\
\hline 4 & 35 & Proliferative & III & Left ovary & Presence of leiomyoma & Western blot, FACS \\
\hline 5 & 38 & Secretory & IV & Right ovary & Dysmenorrhea, pelvic pain & Proliferation, ELISA \\
\hline 6 & 45 & Proliferative & IV & Right ovary & Dysmenorrhea & Cytotoxicity, FACS \\
\hline 7 & 35 & Proliferative & III & Left ovary & Dysmenorrhea & qRT-PCR, western blot \\
\hline 8 & 31 & Secretory & IV & Right ovary & Pelvic pain & Western blot, IF \\
\hline 9 & 28 & Secretory & IV & Left ovary & Dysmenorrhea & Proliferation, EMSA \\
\hline 10 & 36 & Secretory & III & Left ovary & $\begin{array}{l}\text { Pelvic pain, presence of } \\
\text { leiomyoma }\end{array}$ & qRT-PCR, IF, FACS \\
\hline 11 & 30 & Proliferative & IV & Both ovaries & $\begin{array}{l}\text { Dysmenorrhea, presence of } \\
\text { leiomyoma }\end{array}$ & IF, western blot, EMSA \\
\hline 12 & 41 & Proliferative & IV & Both ovaries & Dysmenorrhea & FACS, EMSA \\
\hline 13 & 31 & Proliferative & IV & Right ovary & Dysmenorrhea & IF, FACS \\
\hline 14 & 42 & Secretory & IV & Right ovary & Dysmenorrhea, pelvic pain & Western blot, ELISA \\
\hline 15 & 28 & Secretory & IV & Both ovaries & Intermittent pelvic pain & FACS, IF, proliferation \\
\hline 16 & 25 & Proliferative & IV & Left ovary & Pelvic pain & FACS, ELISA \\
\hline 17 & 38 & Proliferative & III & Right ovary & Dysmenorrhea & Western blot, qRT-PCR \\
\hline 18 & 31 & Proliferative & IV & Both ovaries & Dysmenorrhea & Western blot, ELISA \\
\hline
\end{tabular}

ASRM, American Society for Reproductive Medicine; IF, immunofluorescence.

and cytokines were purchased from Chemicon International (Temecula, CA, USA). Culture flasks and dishes were obtained from BD Biosciences Discovery Labware (Bedford, MA, USA). Tissues were gently rinsed and washed in DMEM containing antibiotics/antimycotics (300 IU/ml penicillin $\mathrm{G}, 300 \mu \mathrm{g} / \mathrm{ml}$ streptomycin and $3 \mu \mathrm{g} / \mathrm{ml}$ fungizone). The tissues were then treated with $0.25 \%$ collagenase type I in DMEM at $37^{\circ} \mathrm{C}$ for $30 \mathrm{~min}$ in a shaking water bath. The cells were then passed through a $70-\mu \mathrm{m}$ sieve (BD Biosciences Discovery Labware). Following sedimentation, the supernatant was transferred to a new tube and the cells were collected by centrifugation. The cells were maintained and proliferated in DMEM supplemented with $10 \% \mathrm{FBS}$ in a humidified atmosphere of $5 \% \mathrm{CO}_{2}$ at $37^{\circ} \mathrm{C}$. The stromal cell-rich supernatant was placed in a culture flask and cells were allowed to adhere for $20 \mathrm{~min}$, and then washed with the medium. Adherent stromal cells were cultured in monolayers in flasks with DMEM/F-12 (1:1) containing antibiotics/antimycotics, $5 \mu \mathrm{g} / \mathrm{ml}$ insulin (Sigma, St. Louis, MO, USA) and $10 \%$ FBS. Culture purity was determined morphologically after hematoxylin and eosin (H\&E) staining. Stromal cells were fusiform, but more round than fibroblasts. Cells were also evaluated immunohistochemically using antibodies to human cytokeratin, vimentin, von Willebrand factor and CD45. The HESCs expressed vimentin, but not cytokeratin, von Willebrand factor or CD45. As defined by these criteria, the purity of the HESCs was $>97 \%$. After the second subculture, the HESCs were cultured in DMEM/F-12 (1:1) containing antibiotics/antimycotics and $10 \%$ FBS. Subsequently, the culture medium was changed to serum-starved (5\% FBS) DMEM/F-12 (1:1), and the cells were incubated for an additional $24 \mathrm{~h}$ prior to treatment.

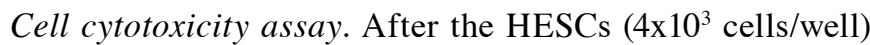
in 96-well plates were treated with various doses of HEABG $(1,10,30,50$ or $70 \mu \mathrm{g} / \mathrm{ml})$ for $48 \mathrm{~h}$, cell viability was determined using the colorimetric WST-1 conversion assay (Roche Diagnostics, Mannheim, Germany). A total of $10 \mu 1$ of WST-1 reagent was added to each well, and the cells were incubated for $2 \mathrm{~h}$ in a humidified incubator at $37^{\circ} \mathrm{C}$ under $5 \% \mathrm{CO}_{2}$. Absorbance was measured in a microplate reader (Tecan Group Ltd., Männedorf, Switzerland) at $450 \mathrm{~nm}$.

Cell proliferation assay. After the HESCs $\left(4 \times 10^{3}\right.$ cells/well) in 96-well plates were pre-treated with various doses of HEABG (30 or $50 \mu \mathrm{g} / \mathrm{ml}$ ), $50 \mu \mathrm{M}$ of an extracellular signal-regulated kinase (ERK) inhibitor (PD98059; Tocris Bioscience, Bristol, $\mathrm{UK}$ ) or $20 \mu \mathrm{M}$ of a c-Jun N-terminal kinase (JNK) inhibitor (SP600125; Tocris Bioscience) for $1 \mathrm{~h}$, the cells were further treated with $10 \mathrm{ng} / \mathrm{ml}$ of TNF- $\alpha$ for $48 \mathrm{~h}$. Cell proliferation 
was determined using the colorimetric WST-1 conversion assay as described above.

Cell cycle analysis. Cell cycle analysis was performed using a FACSCanto II with FACSDiva software (both from BD Biosciences, San Jose, CA, USA). Cells were harvested by trypsin-EDTA treatment and washed with phosphate-buffered saline (PBS) containing $1 \% \mathrm{FBS}$ and $0.1 \% \mathrm{NaN}_{3}$, and fixed with $70 \%$ ethanol at $4^{\circ} \mathrm{C}$ for $20 \mathrm{~min}$. After washing 3 times with ice-cold PBS, the cells were suspended in propidium iodide (PI)-solution (0.001\% Triton X-100, 3.4\% RNase A, $0.005 \%$ PI in PBS). An electronic gate was set on the HESCs using forward and side scatter characteristics. In all the experiments, cells were gated on forward and side scatter to eliminate dead cells and debris.

Flow cytometry. Immunophenotypic analysis of the cells was performed using a FACSCanto II with FACSDiva software (both from BD Biosciences). Cells were harvested by trypsinEDTA treatment and washed with PBS containing 1\% FBS and $0.1 \% \mathrm{NaN}_{3}$. For flow cytometry, the cells were incubated with 2.4G2 (anti-Fc receptor) hybridoma culture supernatant to block non-specific antibody binding and then stained with fluorochrome-conjugated monoclonal antibodies (mAbs). Phycoerythrin (PE)-anti-ICAM-1 (CD54 and MEM-111) and PE-anti-VCAM-1 (CD106 and STA) mAbs were purchased from BioLegend Inc. (San Diego, CA, USA). Background fluorescence was determined by measuring the fluorescent signal from cells stained with fluorochrome-labeled isotype-matched non-reactive $\mathrm{mAbs}$ for $30 \mathrm{~min}$ at $4^{\circ} \mathrm{C}$. An electronic gate was set on the HESCs using forward and side scatter characteristics. In all the experiments, cells were gated on forward and side scatter to eliminate dead cells and debris.

Immunofluorescence staining. For immunofluorescence analysis, the cells were cultured on 12-mm glass coverslips (Paul Marienfeld GmbH \& Co. KG, Lauda-Königshofen, Germany) and fixed with cold $4 \%$ paraformaldehyde in $0.1 \mathrm{M}$ phosphate buffer (PB) for $10 \mathrm{~min}$. Subsequently, the fixative was removed by washing the coverslips 3 times for 5 min each with cold PBS followed by permeabilization with $0.1 \%$ Triton X-100 in PBS for $5 \mathrm{~min}$. The cells were washed again with cold PBS and then incubated with $1 \%$ bovine serum albumin (Sigma) for $60 \mathrm{~min}$ at room temperature. Excess solution was shaken off and the cells were incubated for $16-18 \mathrm{~h}$ at $4^{\circ} \mathrm{C}$ with PE-anti-ICAM-1 or PE-anti-VCAM-1 (both from BioLegend) mAbs diluted 1:100. Following incubation with the primary antibodies, the cells were washed 3 times for 5 min each with cold PBS. The cells were then rinsed in cold PBS and mounted on glass slides using Vectashield ${ }^{\circledR}$ (Vector Laboratories, Burlingame, CA, USA). Labeled cells were examined using an Olympus BX50 microscope equipped with fluorescent epi-illumination. Photomicrographs were acquired digitally at 1360x1024 pixel resolution with an Olympus DP70 digital camera.

Preparation of cytosolic and nuclear cell extracts. Cells were resuspended in $70 \mu \mathrm{l}$ of buffer A [10 mM HEPES (pH 7.9), $1.5 \mathrm{mM} \mathrm{MgCl}_{2}, 10 \mathrm{mM} \mathrm{KCl,} 0.5 \mathrm{mM}$ DTT, $0.5 \mathrm{mM}$ PMSF, protease inhibitor cocktail and phosphatase inhibitor cocktail I and II (both from Sigma)] and incubated on ice. After
15 min, $0.5 \%$ nonyl phenoxypolyethoxylethanol P (NP)-40 was added to lyse the cells, followed by vortexing for $10 \mathrm{sec}$. Cytosolic cell extracts were obtained after centrifugation at $6,500 \mathrm{rpm}$ for $60 \mathrm{sec}$ at $4^{\circ} \mathrm{C}$. Nuclei were resuspended in $50 \mathrm{ml}$ of buffer C [20 mM HEPES (pH 7.9), $1.5 \mathrm{mM} \mathrm{MgCl}_{2}, 420 \mathrm{mM}$ $\mathrm{NaCl}, 0.2 \mathrm{mM}$ EDTA, 25\% v/v glycerol, $0.5 \mathrm{mM}$ PMSF and protease inhibitor cocktail] and incubated on ice for $20 \mathrm{~min}$ with gentle pipetting every $5 \mathrm{~min}$. Nuclear cell extracts were recovered after centrifugation for $10 \mathrm{~min}$ at $12,000 \mathrm{rpm}$ at $4^{\circ} \mathrm{C}$. Protein concentration was determined using the Bradford protein assay reagent (Bio-Rad, Hercules, CA, USA).

Western blot analysis. Equal amounts of protein samples were heated for $10 \mathrm{~min}$ at $95^{\circ} \mathrm{C}$ in sample buffer and separated by performing sodium dodecyl sulfate polyacrylamide gel electrophoresis (SDS-PAGE) on $12 \%$ SDS polyacrylamide gel, using a Mini-Protean III system (Bio-Rad). Proteins were transferred onto a polyvinylidene difluoride (PVDF) membrane using a semi-dry transfer apparatus (both from Bio-Rad). The blotted PVDF membrane was blocked with $5 \%$ skim milk in Tris-buffered saline (TBS) at room temperature for $2 \mathrm{~h}$. The membrane was then incubated overnight at $4^{\circ} \mathrm{C}$ with anti-ICAM-1 (sc-1511), anti-VCAM-1 (sc-1504),

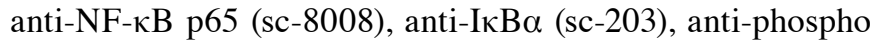
(p)-IкB $\alpha$ (sc-7977-R) (all from Santa Cruz Biotechnology, Inc., Santa Cruz, CA, USA), anti-p-ERK (p44/42 MAPK) (4370), anti-ERK (p44/42 MAPK) (9102), anti-p-JNK (4668), anti-JNK (9258), anti-p-p38 MAPK (9215) and anti-p38 MAPK mAbs (9212) (Cell Signaling Technology, Danvers, MA, USA). These antibodies, as well as that for $\alpha$-tubulin (MU121-UC; BioGenex Laboratories, Inc., San Ramon, CA, USA) and $\beta$-actin (8226; Abcam, Cambridge, UK), were incubated with the membranes at a dilution of 1:1,000 in TBS containing 2\% skim milk. After 3 washes with TBS-T (TBS containing 0.1\% Tween-20), the membrane was incubated for $2 \mathrm{~h}$ at room temperature with the secondary antibody, rabbit anti-goat IgG horseradish peroxidase (HRP) conjugate (sc-2768), goat anti-mouse IgG HRP conjugate (sc-2031), goat anti-rabbit IgG HRP conjugate (sc-2004) (all from Santa Cruz Biotechnology, Inc.) and goat anti-rabbit IgG HRP (7074; Cell Signaling Technology) diluted 1:2,000, and re-washed 3 times with TBS-T. Immunoreactivity was detected using enhanced chemiluminescence (ECL; SuperSignal West Pico Chemiluminescent Substrate kit; Pierce, Rockford, IL, USA) according to the manufacturer's instructions. Images were acquired and the signals were quantified using a Fujifilm LAS-3000 imaging system (Fujifilm, Tokyo, Japan).

Quantitative reverse transcriptase-PCR ( $q R T-P C R)$. Total RNA was then isolated from the cells using TRIzol reagent (Invitrogen, Carlsbad, CA, USA) according to the manufacturer's instructions and treated with DNase (DNA-free kit; Ambion, Austin, TX, USA). Total RNA (500 ng) was converted into cDNA (M-MLV Reverse Transcriptase; Promega, Madison, WI, USA). qRT-PCR amplification was performed using the following qRT-PCR primers: ICAM-1 sense, 5'-CCGTGAAT GTGCTCTCCC-3' and antisense, 5'-ATTTCTTGATCTT CCGCTGG-3' (GenBank accession no. NM_000201); and VCAM-1 sense, 5'-CAGGTGGAGCTCTACTCATTCC-3' and antisense, 5'-GAATAGTCTCCCCCTTAAGTAATTC-3' (GenBank accession no. NM_001078). For normalization, the 
GAPDH gene was amplified using the following primers: GAPDH sense, 5'-GAAGATGGTGATGGGATTTC-3' and antisense, 5'-GAAGGTGAAGGTCGGAGT-3' (GenBank accession no. NM_002046). qRT-PCR amplification was performed in a Rotor-Gene 6000 (Corbett Life Science, Sydney, Australia) with QuantiTect ${ }^{\circledR}$ SYBR $^{\circledR}$-Green PCR Master Mix (Qiagen, Hilden, Germany). qRT-PCR amplification of ICAM-1, VCAM-1 and GAPDH genes were carried out for 50 cycles at $94^{\circ} \mathrm{C}$ for $10 \mathrm{sec}, 56^{\circ} \mathrm{C}$ for $15 \mathrm{sec}$ and $72^{\circ} \mathrm{C}$ for $15 \mathrm{sec}$. Melting curve analysis was conducted for $30 \mathrm{sec}$ at $55-99^{\circ} \mathrm{C}$. Amplification products exhibited single, sharp peaks, indicating that the primers amplified only one specific PCR product. All the samples were amplified in triplicate. An amplification reaction containing no template was used as a control to establish non-specific background amplification. Data were analyzed using the Rotor-Gene 6000 program (Corbett Life Science). Gene expression levels were calculated using the formula, $\mathrm{R} 0=\mathrm{RCt} \mathrm{x}(1+\mathrm{E})-\mathrm{Ct}$ and were normalized to GAPDH expression levels.

Enzyme-linked immunosorbent assay (ELISA). Cells cultured in 96 -well plates $\left(4 \times 10^{3} /\right.$ well) in DMEM/F-12 medium in the presence of 5\% FBS were pre-treated with or without HEABG $(50 \mu \mathrm{g} / \mathrm{ml})$ for $1 \mathrm{~h}$ and stimulated with TNF- $\alpha(10 \mathrm{ng} / \mathrm{ml})$ for $15 \mathrm{~h}$, after which supernatants were harvested. The concentrations of IL-6 in the supernatants were measured using standard ELISA kits (R\&D Systems, Minneapolis, MN, USA). Diluted supernatant (1:100) and HRP-conjugated anti-IL-6 antibodies were added separately into each antibody-coated well for evaluation. Plate wells were covered with a fresh plastic sealer and incubated at room temperature for $2 \mathrm{~h}$ with gentle shaking. The solution was then discarded, and the wells were washed 6 times with wash buffer. Chromogen solution (tetramethylbenzidine) was added to the wells and incubated for $20 \mathrm{~min}$ at room temperature, followed by the addition of stop solution. The amount of conjugate bound to each well was quantified photometrically from these colored products by measuring the optical density at $450 \mathrm{~nm}$. A concentration of IL-6 was extrapolated from a standard curve using recombinant IL-6. The sensitivity of the ELISA assay of IL-6 was $\geq 0.7 \mathrm{pg} / \mathrm{ml}$.

Electrophoretic mobility shift assay (EMSA). The cells were pre-treated with HEABG $(50 \mu \mathrm{g} / \mathrm{ml})$ for $1 \mathrm{~h}$ and then stimulated with TNF- $\alpha(10 \mathrm{ng} / \mathrm{ml})$ for $30 \mathrm{~min}$ at $37^{\circ} \mathrm{C}$ prior to the extraction of nuclear protein. The NF- $\kappa \mathrm{B}$ oligonucleotide (5'-AGTTGAGGGGACTTTCCCAGGC-3') and AP-1 oligonucleotide (5'-CGCTTGATGACTCAGCCGGAA-3') (Bioneer, Inc., Seoul, Korea) were end-labeled with biotin. Nuclear protein extracts $(10 \mu \mathrm{g})$ were incubated with $20 \mathrm{fmol}$ of biotin-labeled NF- $\mathrm{B}$ oligonucleotide and AP-1 oligonucleotide for $20 \mathrm{~min}$ prior to loading onto $4 \%$ (for $\mathrm{NF}-\kappa \mathrm{B}$ ) and $6 \%$ (for AP-1) non-denaturing polyacrylamide gels. Each gel was run at room temperature in $0.3 \mathrm{X} \mathrm{TBE}$ buffer at $100 \mathrm{~V}$ until the bromophenol blue dye reached the bottom of the gel. When electrophoresis was completed, the gel was blotted onto a Biodyne ${ }^{\circledR}$ B Nylon Membrane (Pierce), and labeled oligonucleotides were detected using the LightShift Chemiluminescent EMSA kit according to the manufacturer's instructions (Pierce). Images were acquired and the signals were quantified using the LAS-3000 imaging system.

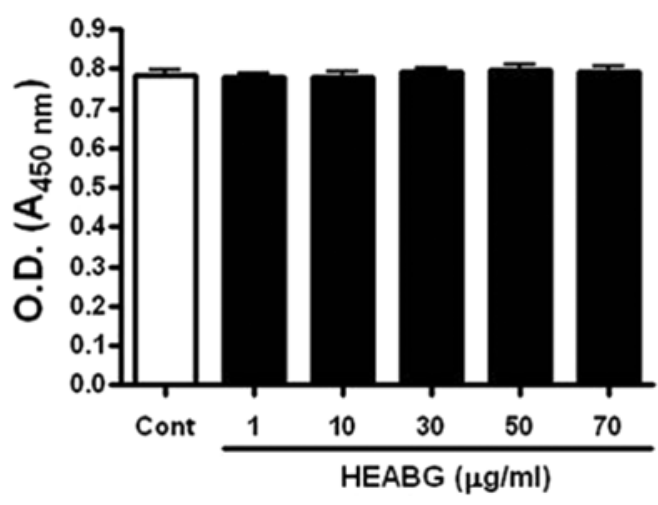

Figure 1. Effect of hexane extract of aged black garlic (HEABG) on the viability of human endometrial stromal cells (HESCs). After the HESCs were cultured for $24 \mathrm{~h}$ and then serum-starved ( $5 \% \mathrm{FBS}$ ) for $24 \mathrm{~h}$, they were treated with various doses of $\operatorname{HEABG}(1,10,30,50$ or $70 \mu \mathrm{g} / \mathrm{ml})$ for $48 \mathrm{~h}$, and cell viability was determined using the WST-1 assay. Data are representative of 3 independent experiments with similar results. Results are the means \pm SD of pentaplicates.

Statistical analysis. The results of the present study are expressed as the means \pm SD under all conditions and statistically analyzed using a two-tailed Student's t-test. A value of $\mathrm{P}<0.05$ was considered to indicate a statistically significant difference.

\section{Results}

Effect of HEABG on the viability of HESCs. We first examined the cytotoxic effects of HEABG on the HESCs by WST-1 assay. HEABG did not affect the viability of the HESCs up to a concentration of $70 \mu \mathrm{g} / \mathrm{ml}$ (Fig. 1).

Effect of HEABG on the proliferation of HESCs. Since enhanced endometrial cell proliferation is an important pathological feature of human endometriosis, we evaluated the effect of HEABG on the inhibition of TNF- $\alpha$-stimulated HESC proliferation by WST-1 assay. The stimulation of HESCs with TNF- $\alpha(10 \mathrm{ng} / \mathrm{ml})$ for $48 \mathrm{~h}$ significantly enhanced HESC proliferation (Fig. 2). By contrast, HESCs pre-treated with HEABG (30 and $50 \mu \mathrm{g} / \mathrm{ml}$ ) exhibited a significant reduction in cell proliferation induced by $\mathrm{TNF}-\alpha$, indicating that HEABG used at non-toxic concentrations in HESCs exhibits a significant inhibitory effect on the proliferation of HESCs (Fig. 2). Furthermore, the growth-promoting effect of TNF- $\alpha$ in HESCs was also completely blocked by the treatment with either the ERK inhibitor, PD98059 (50 $\mu \mathrm{M})$, or the JNK inhibitor, SP600125 $(20 \mu \mathrm{M})$, for $1 \mathrm{~h}$ prior to stimulation with TNF- $\alpha$ (10 ng/ml). This finding led us to investigate the effect of HEABG on TNF- $\alpha$-induced MAPK activation. Treatment of the HESCs with TNF- $\alpha$ clearly induced the phosphorylation of ERK, JNK and p38 MAPK. Notably, pre-treatment with HEABG resulted in the inhibition of the TNF- $\alpha$-induced ERK and JNK phosphorylation, but not p38 MAPK phosphorylation (Fig. 3). Taken together, these results indicate that the TNF- $\alpha$-induced enhancement of the proliferation of HESCs is mediated through the ERK/MAPK and JNK/MAPK signal transduction pathways. 


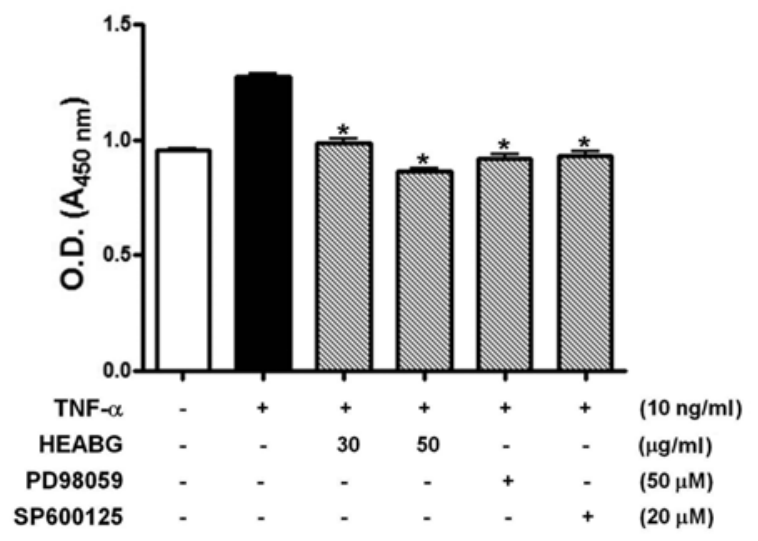

Figure 2. Effect of hexane extract of aged black garlic (HEABG) on the proliferation of TNF- $\alpha$-stimulated human endometrial stromal cells (HESCs). After the HESCs were cultured for $24 \mathrm{~h}$ and then serum-starved (5\% FBS) for $24 \mathrm{~h}$, they were treated with various doses of HEABG (30 or $50 \mu \mathrm{g} / \mathrm{ml}), 50 \mu \mathrm{M}$ of an ERK inhibitor (PD98059) or $20 \mu \mathrm{M}$ of a JNK inhibitor (SP600125) for $1 \mathrm{~h}$, and cell proliferation was determined using the WST-1 assay. Data are representative of 3 independent experiments with similar results. Results are the means \pm SD of pentaplicates. ${ }^{*} \mathrm{P}<0.001$ compared with the TNF- $\alpha$-treated group as determined by a t-test.

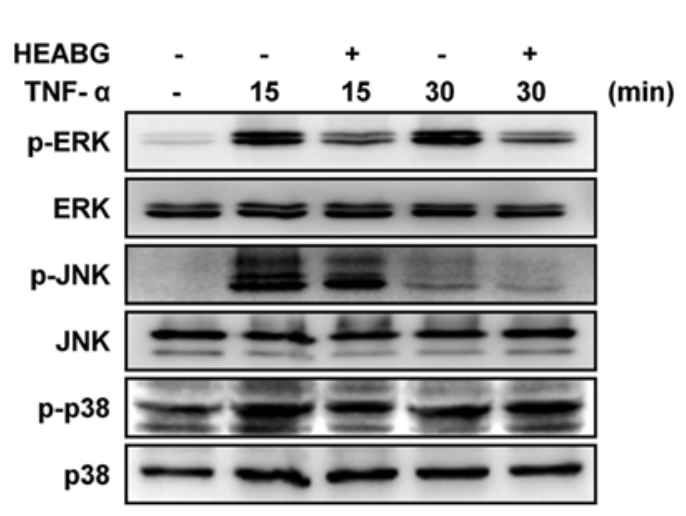

Figure 3. Western blot analysis of the effects of hexane extract of aged black garlic (HEABG) on the activation of p-ERK, ERK, p-JNK, JNK, p-p38 and p38 in TNF- $\alpha$-treated human endometrial stromal cells (HESCs). Cells were cultured in the presence or absence of HEABG $(50 \mu \mathrm{g} / \mathrm{ml})$ for $1 \mathrm{~h}$, and then stimulated with TNF- $\alpha(10 \mathrm{ng} / \mathrm{ml})$ for $30 \mathrm{~min}$. Data are representative of 3 independent experiments with similar results.

Effect of HEABG on the cell cycle in HESCs. The effect of HEABG on the cell cycle of HESCs was determined by flow cytometric analysis. Treatment of the HESCs with TNF- $\alpha$ $(10 \mathrm{ng} / \mathrm{ml})$ for $15 \mathrm{~h}$ significantly reduced the proportion of cells in the G0/G1 phase and increased the number of cells in the $\mathrm{S}$ and $\mathrm{G} 2 / \mathrm{M}$ phase (Fig. 4). Pre-treatment with HEABG (30 and $50 \mu \mathrm{g} / \mathrm{ml}$ ) markedly suppressed these cell cycle alterations (Fig. 4). Furthermore, the stimulating effects of TNF- $\alpha$ on cell cycle progression in HESCs were also completely abolished by treatment with either the ERK inhibitor, PD98059 $(50 \mu \mathrm{M})$, or the JNK inhibitor, SP600125 $(20 \mu \mathrm{M})$, for $1 \mathrm{~h}$ prior to stimulation with TNF- $\alpha(10 \mathrm{ng} / \mathrm{ml})$, indicating that the TNF- $\alpha$ induced promotion of the cell cycle progression of HESCs is mediated through the ERK/MAPK and JNK/MAPK signal transduction pathways (Fig. 4).
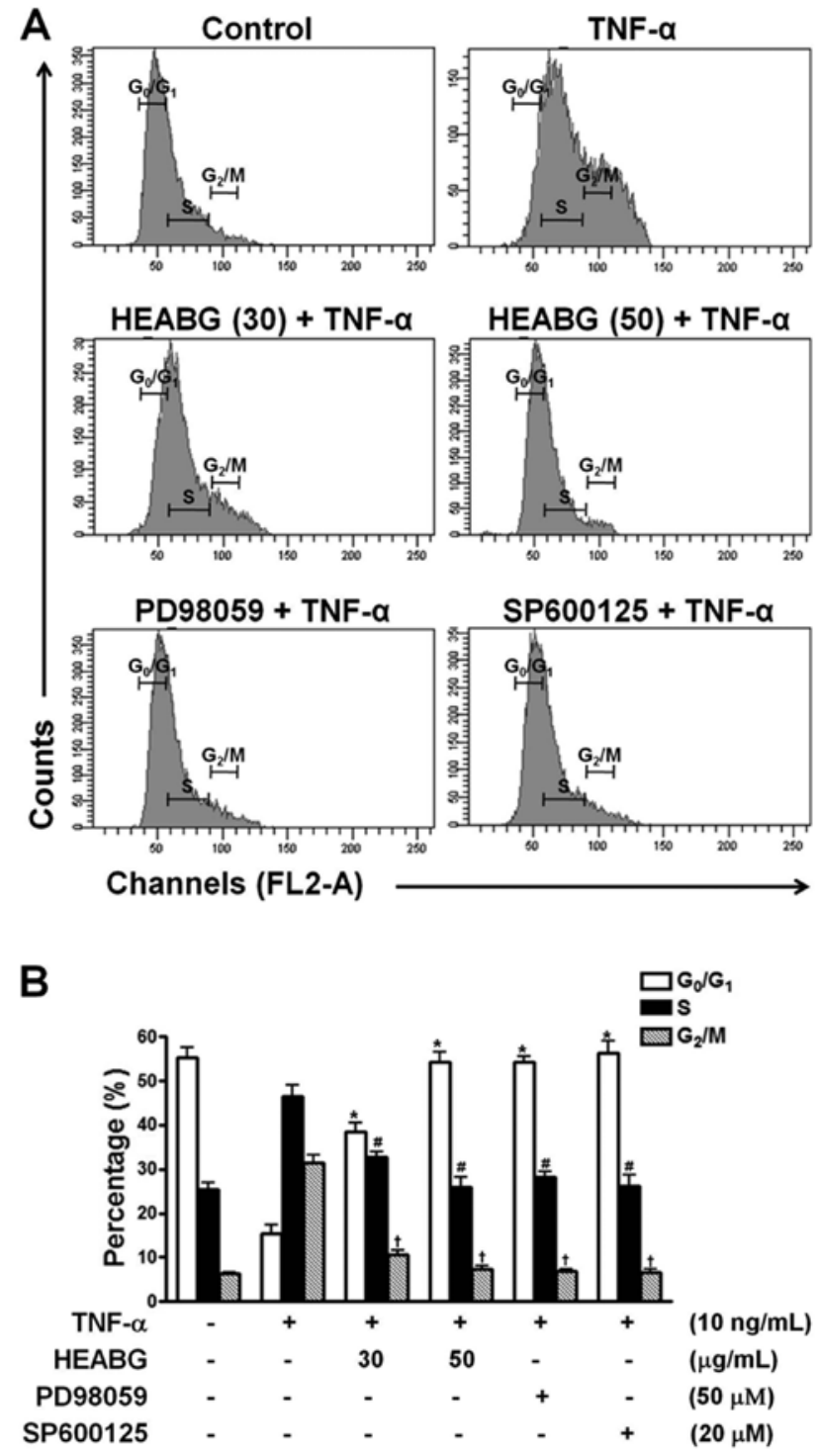

Figure 4. Flow cytometric analysis of the effect of hexane extract of aged black garlic (HEABG) on the cell cycle of human endometrial stromal cells (HESCs). (A) HESCs were pre-treated with HEABG (30 and $50 \mu \mathrm{g} / \mathrm{ml}$ ), $50 \mu \mathrm{M}$ of an ERK inhibitor (PD98059) or $20 \mu \mathrm{M}$ of a JNK inhibitor (SP600125) for $1 \mathrm{~h}$, and then stimulated with TNF- $\alpha(10 \mathrm{ng} / \mathrm{ml})$ for $15 \mathrm{~h}$. (B) Data in histograms are also plotted in bar graphs and are expressed as the means \pm SD. Data are representative of 3 independent experiments with similar results. ${ }^{*} \mathrm{P}<0.01$ compared with the TNF- $\alpha$-treated group as determined by a t-test.

Suppression of ICAM-1 and VCAM-1 transcription by HEABG. To analyze the transcription of cell adhesion molecules in HESCs, the mRNA expression of ICAM-1 and VCAM-1 was evaluated by qRT-PCR analysis. Treatment of the HESCs with TNF- $\alpha(10 \mathrm{ng} / \mathrm{ml})$ for $15 \mathrm{~h}$ significantly increased the mRNA expression levels of ICAM-1 and VCAM-1 (Fig. 5). Pre-treatment with HEABG $(50 \mu \mathrm{g} / \mathrm{ml})$ markedly suppressed the TNF- $\alpha$-induced ICAM-1 and VCAM-1 mRNA expression (42.5 and 44.6\% inhibition, respectively; $\mathrm{P}<0.005$ ) (Fig. 5).

Inhibition of cell surface expression of ICAM-1 and VCAM-1 by $H E A B G$. To analyze cell adhesion molecule expression on endometrial stromal cell surfaces, ICAM-1 and VCAM-1 expression was evaluated by flow cytometry. Treatment of the 
ICAM-1

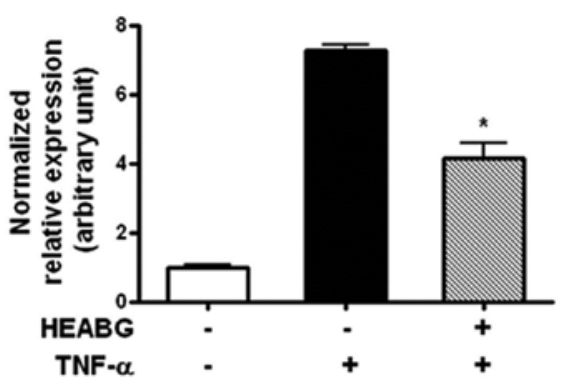

VCAM-1

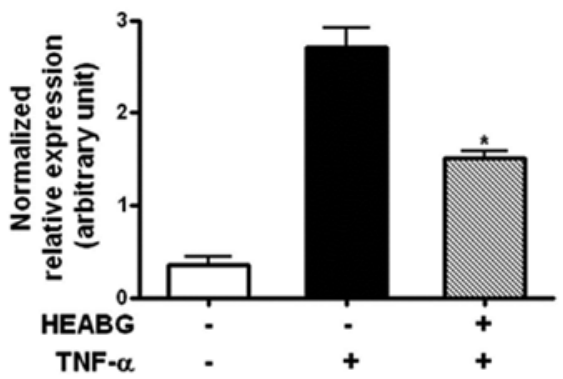

Figure 5. Quantitative real-time RT-PCR analysis of the effect of HEABG on the gene expression of adhesion molecules in TNF- $\alpha$-activated HESCs. HESCs were pre-treated with HEABG $(50 \mu \mathrm{g} / \mathrm{ml})$ for $1 \mathrm{~h}$, and then stimulated with TNF- $\alpha(10 \mathrm{ng} / \mathrm{ml})$ for $15 \mathrm{~h}$. Data are representative of 3 independent experiments with similar results. Results are expressed as ratios of intercellular adhesion molecule-1 (ICAM-1) and vascular cell adhesion molecule-1 (VCAM-1) mRNA normalized to GAPDH mRNA, plotted in bar graphs and expressed as means \pm SD. ${ }^{*} \mathrm{P}<0.005$ compared with the TNF- $\alpha$-treated group as determined by a t-test.
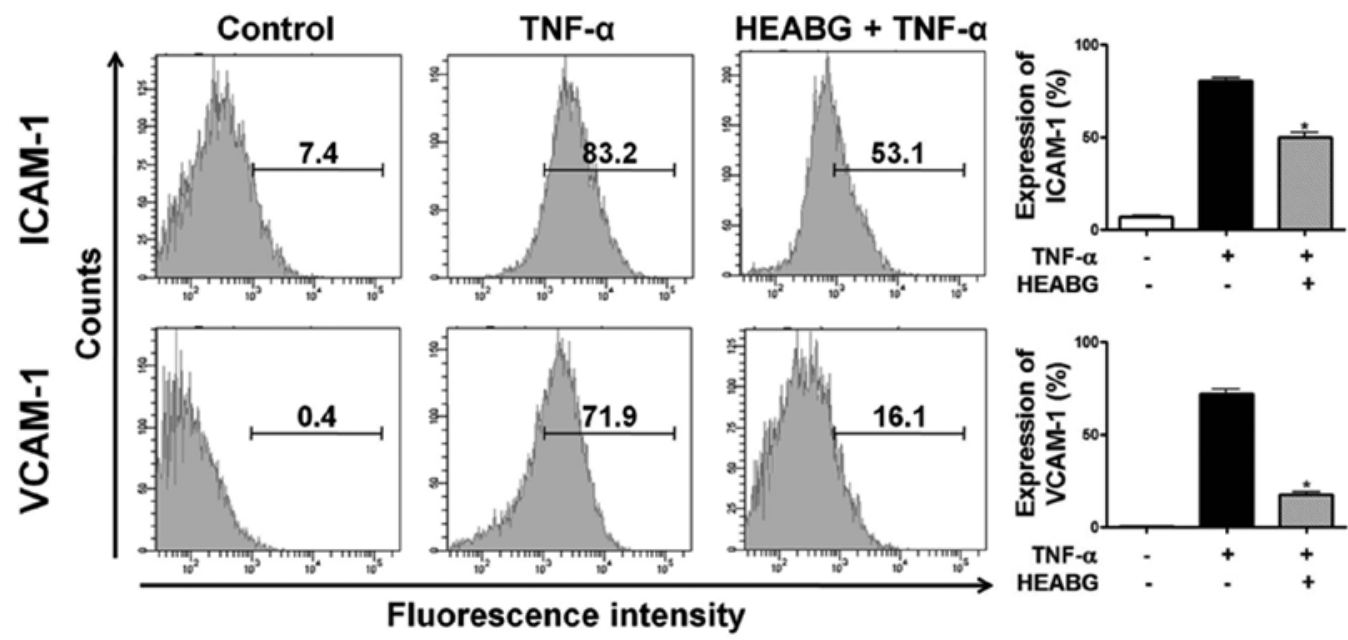

Figure 6. Flow cytometric analysis of the effect of hexane extract of aged black garlic (HEABG) on the expression of intercellular adhesion molecule-1 (ICAM-1) and vascular cell adhesion molecule-1 (VCAM-1) in TNF- $\alpha$-activated human endometrial stromal cells (HESCs). HESCs were pre-treated with HEABG (50 $\mu \mathrm{g} / \mathrm{ml})$ for $1 \mathrm{~h}$, and then stimulated with TNF- $\alpha(10 \mathrm{ng} / \mathrm{ml})$ for $15 \mathrm{~h}$. Data in histograms are also plotted in bar graphs and are expressed as the means \pm SD. Data are representative of 3 independent experiments with similar results. ${ }^{*} \mathrm{P}<0.001$ compared with the TNF- $\alpha$-treated group as determined by a t-test.

HESCs with TNF- $\alpha$ (10 ng/ml) for $15 \mathrm{~h}$ markedly induced the cell surface expression of ICAM-1 and VCAM-1 proteins (Fig. 6). Pre-treatment with HEABG $(50 \mu \mathrm{g} / \mathrm{ml})$ significantly suppressed the TNF- $\alpha$-induced ICAM-1 and VCAM-1 cell surface expression (37.6 and 75.6\% inhibition, respectively; $\mathrm{P}<0.001$ ) (Fig. 6).

Suppression of total cellular ICAM-1 and VCAM-1 protein expression by $H E A B G$. The incubation of HESCs with TNF- $\alpha$ $(10 \mathrm{ng} / \mathrm{ml})$ for $15 \mathrm{~h}$ markedly increased the protein levels of total cellular ICAM-1 and VCAM-1, as revealed by immunofluorescence microscopic analysis (Fig. 7). Pre-treatment with HEABG $(50 \mu \mathrm{g} / \mathrm{ml})$ for $1 \mathrm{~h}$ significantly suppressed the total cellular protein expression of ICAM-1 and VCAM-1 in HESCs induced by TNF- $\alpha$ (Fig. 7).

Additionally, western blot analysis revealed a single specific band correlating for ICAM-1 and VCAM-1 in the HESCs treated with TNF- $\alpha(10 \mathrm{ng} / \mathrm{ml})$ for $15 \mathrm{~h}$ (Fig. 8). Importantly, this effect was effectively inhibited by pre-treatment with HEABG (50 $\mu \mathrm{g} / \mathrm{ml})$ for $1 \mathrm{~h}$ (Fig. 8). The protein expression of ICAM-1 and VCAM-1 in the TNF- $\alpha$-activated HESCs following treatment with HEABG, as measured by flow cytometric analysis (Fig. 6), immunofluorescence microscopic analysis (Fig. 7) and western blot analysis (Fig. 8), was in accordance with the transcription patterns of ICAM-1 and VCAM-1 shown by qRT-PCR analysis (Fig. 5), clearly indicating that both the cell surface and cytoplasmic protein, as well as the mRNA expression of ICAM-1 and VCAM-1 in the HESCs induced by TNF- $\alpha$ was definitely inhibited by HEABG.

Inhibition of secretion of IL- 6 by HEABG. The levels of IL-6 secreted by HESCs were evaluated by ELISA. Treatment of the HESCs with TNF- $\alpha(10 \mathrm{ng} / \mathrm{ml})$ for $15 \mathrm{~h}$ markedly induced the secretion of IL-6 (Fig. 9). HEABG (50 $\mu \mathrm{g} / \mathrm{ml})$ potently suppressed the TNF- $\alpha$-induced secretion of IL- 6 from HESCs (60.0\% inhibition; $\mathrm{P}<0.01)$ (Fig. 9).

Inhibition of the TNF- $\alpha$-induced translocation of $N F-\kappa B$ and phosphorylation of $I \kappa B \alpha$ by $H E A B G$. To determine whether the activation of $N F-\kappa B$ by $T N F-\alpha$ can be inhibited by 
A
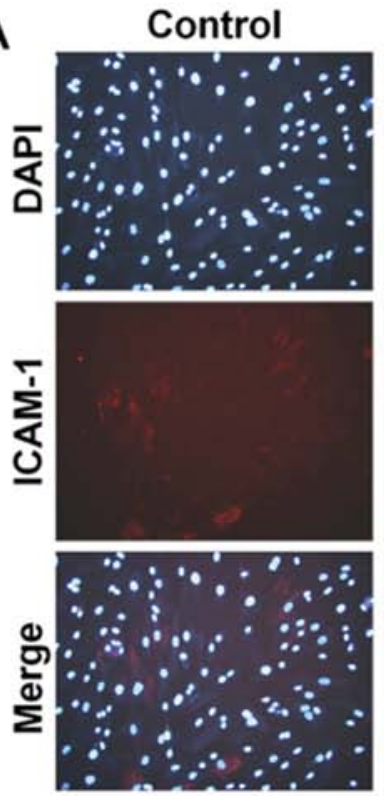

B
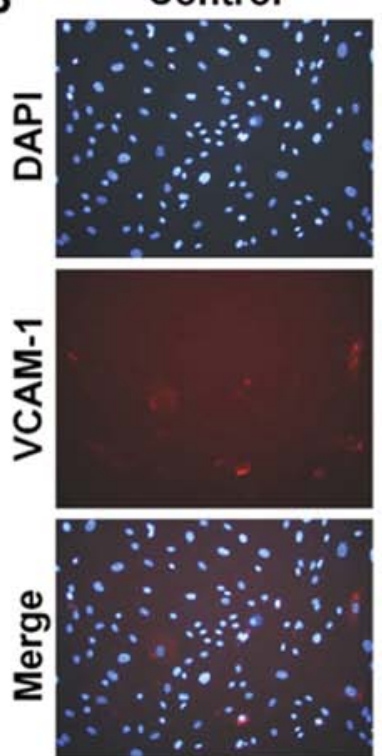

TNF-a
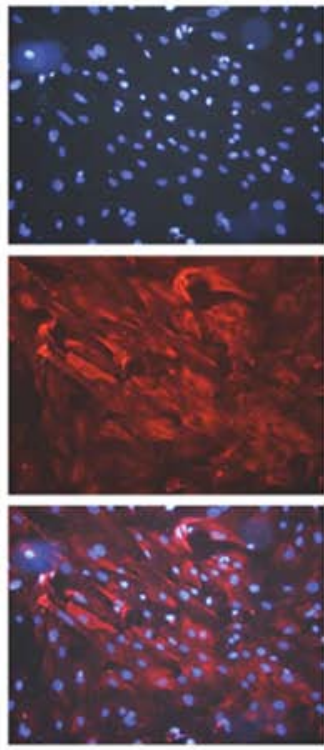

TNF-a
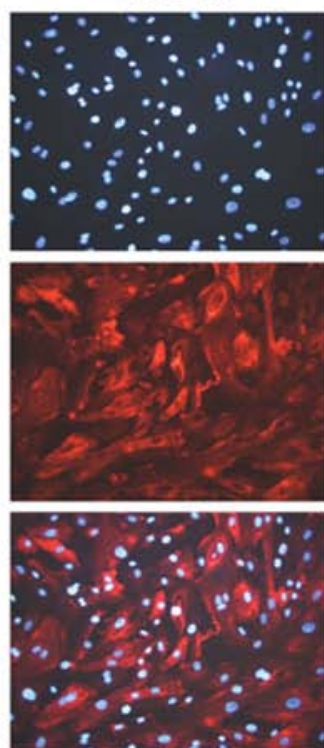

HEABG + TNF- $\alpha$
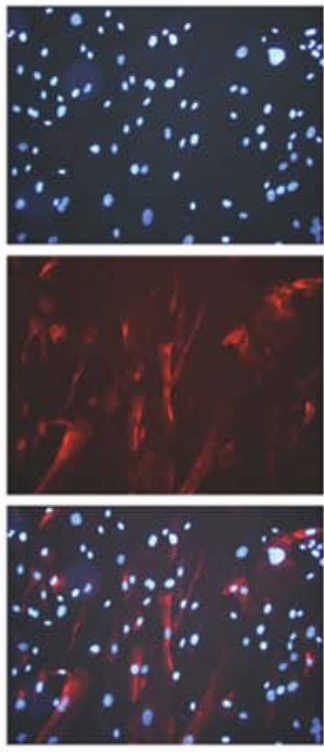

HEABG + TNF- $\alpha$
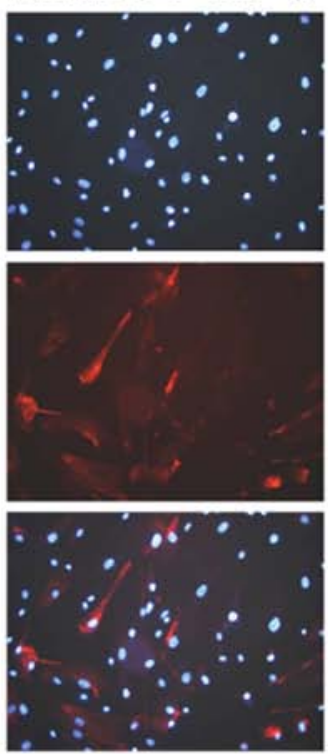

Figure 7. Fluorescence microscopic detection of the effect of hexane extract of aged black garlic (HEABG) on the total cellular expression of (A) intercellular adhesion molecule-1 (ICAM-1) and (B) vascular cell adhesion molecule-1 (VCAM-1) in TNF- $\alpha$-treated human endometrial stromal cells (HESCs). Cells were cultured in the presence or absence of HEABG $(50 \mu \mathrm{g} / \mathrm{ml})$ for $1 \mathrm{~h}$, then stimulated with TNF- $\alpha(10 \mathrm{ng} / \mathrm{ml})$ for $15 \mathrm{~h}$. Images were observed under a fluorescence microscope at x200 magnification. Data are representative of 3 independent experiments with similar results.

HEABG, experiments were carried out to measure the major components of the NF- $\kappa \mathrm{B}$ complex. Western blot analysis indicated that TNF- $\alpha$ induced the translocation of NF- $\kappa \mathrm{B}$ p65 from the cytosol to the nucleus (Fig. 10). Additionally, treatment of the HESCs with TNF- $\alpha(10 \mathrm{ng} / \mathrm{ml})$ for $1 \mathrm{~h}$ induced the phosphorylation and degradation of the $\mathrm{NF}-\kappa \mathrm{B}$ inhibitor, $\mathrm{I} \kappa \mathrm{B} \alpha$, in the cytosol (Fig. 10). Pre-treatment with $50 \mu \mathrm{g} / \mathrm{ml}$ HEABG for $1 \mathrm{~h}$ blocked the TNF- $\alpha$-induced nuclear translocation of NF- $\kappa \mathrm{B}$ p 65 from the cytosol to the nucleus and significantly inhibited the TNF- $\alpha$-induced phosphorylation and degradation of $\mathrm{I} \kappa \mathrm{B} \alpha$ (Fig. 10). These results suggest that HEABG inhibits the translocation of $N F-\kappa B$ from the cytosol to the nucleus in the TNF- $\alpha$-activated HESCs by the inhibition of $\mathrm{I} \kappa \mathrm{B} \alpha$ degradation, which is due to the inhibition of $\mathrm{I} \kappa \mathrm{B} \alpha$ phosphorylation.

Attenuation of TNF- $\alpha$-induced activation of $N F-\kappa B$ and AP-1 by $H E A B G$. To further investigate the mechanism responsible for the inhibitory effect of HEABG on ICAM-1 and VCAM-1 expression, we examined the effect of HEABG on $\mathrm{NF}-\kappa \mathrm{B}$ and AP-1 activation by EMSA. Under control conditions, the

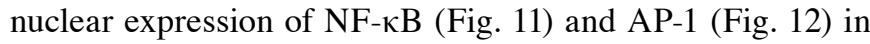
HESCs was barely detectable. However, the stimulation of the HESCs with TNF- $\alpha(10 \mathrm{ng} / \mathrm{ml})$ led to the appearance of NF- $\kappa \mathrm{B}$ (Fig. 11) and AP-1 (Fig. 12) as a shifted band. Pre-treatment with HEABG $(50 \mu \mathrm{g} / \mathrm{ml})$ significantly reduced the density of 


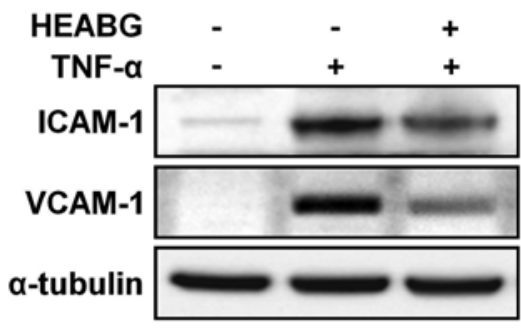

Figure 8. Western blot detection of the effect of hexane extract of aged black garlic (HEABG) on the total cellular expression of intercellular adhesion molecule-1 (ICAM-1) and vascular cell adhesion molecule-1 (VCAM-1) in TNF- $\alpha$-activated human endometrial stromal cells (HESCs). Cells were cultured in the presence or absence of HEABG $(50 \mu \mathrm{g} / \mathrm{ml})$ for $1 \mathrm{~h}$, and then stimulated with TNF- $\alpha(10 \mathrm{ng} / \mathrm{ml})$ for $15 \mathrm{~h}$. Data are representative of 3 independent experiments with similar results.

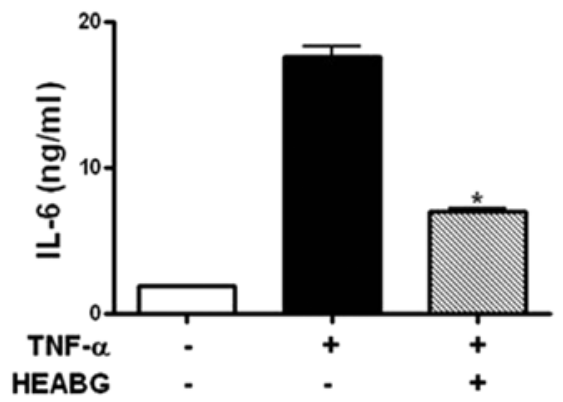

Figure 9. ELISA detection of the effect of hexane extract of aged black garlic (HEABG) on the secretion of IL- 6 by TNF- $\alpha$-activated human endometrial stromal cells (HESCs). Cells were cultured in the presence or absence of HEABG $(50 \mu \mathrm{g} / \mathrm{ml})$ for $1 \mathrm{~h}$, and then stimulated with TNF- $\alpha(10 \mathrm{ng} / \mathrm{ml})$ for $15 \mathrm{~h}$. Data are representative of 3 independent experiments with similar results. Results in bar graphs are expressed as means $\pm \mathrm{SD}$ of triplicates. ${ }^{*} \mathrm{P}<0.01$ compared with the TNF- $\alpha$-treated group as determined by a t-test.

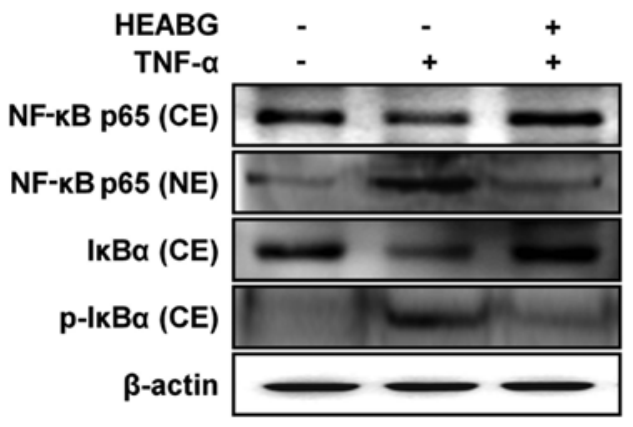

Figure 10. Western blot analysis of the effect of hexane extract of aged black garlic (HEABG) on the nuclear translocation of NF- $\mathrm{KB}$ in TNF- $\alpha$-activated human endometrial stromal cells (HESCs). Cells were cultured in the presence or absence of HEABG $(50 \mu \mathrm{g} / \mathrm{ml})$ for $1 \mathrm{~h}$, and then stimulated with TNF- $\alpha(10 \mathrm{ng} / \mathrm{ml})$ for $1 \mathrm{~h}$. Thereafter, the nuclear fraction was analyzed for NF- $\mathrm{KB}$ p65 translocation from the cytosol into the nucleus by western blot

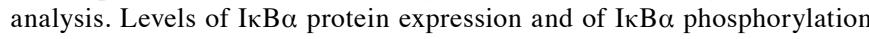
in the cytosol were also analyzed. Data are representative of 3 independent experiments with similar results.

the NF- $\kappa$ B (Fig. 11) and AP-1 (Fig. 12) shifted band (46.7 and $38.5 \%$ inhibition, $\mathrm{P}<0.01$, respectively). These results indicate that $\mathrm{HEABG}$ potently inhibits the activation of $N F-\kappa B$ and AP-1 transcription factors induced by TNF- $\alpha$ in HESCs.

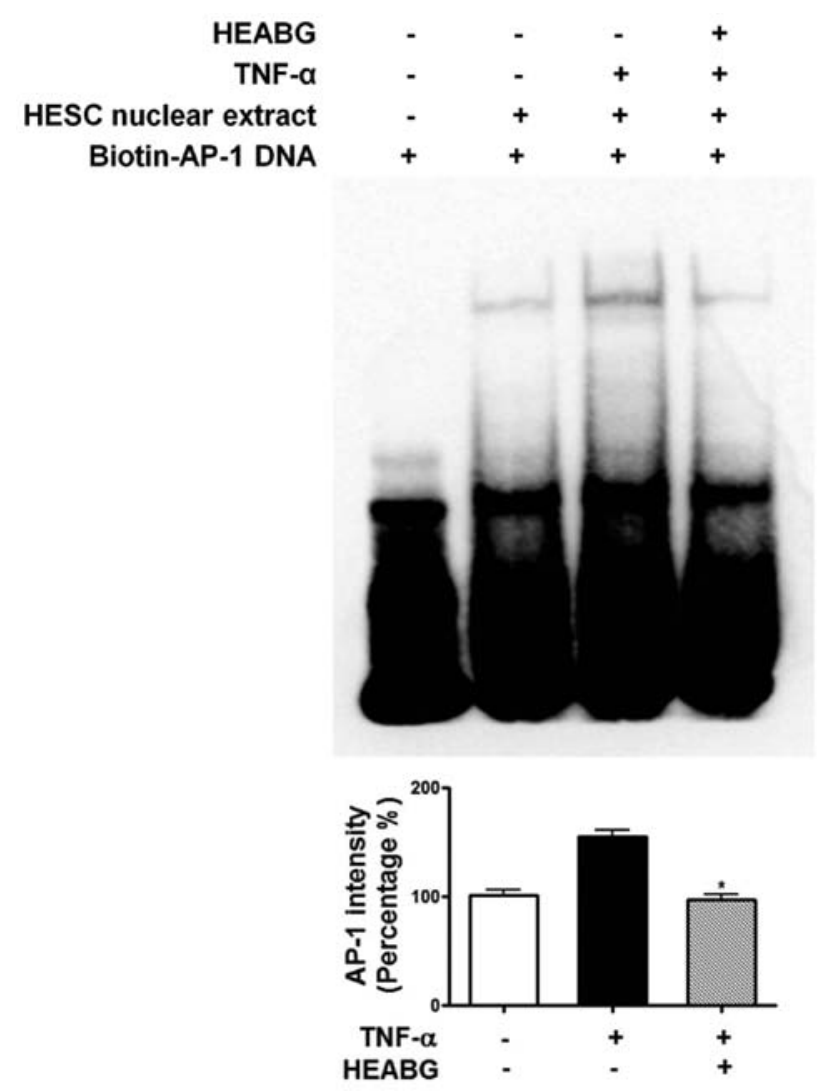

Figure 11. Electrophoretic mobility gel shift assay (EMSA) detection of the effect of hexane extract of aged black garlic (HEABG) on the binding activity of NF- $\mathrm{kB}$ with its target DNA in TNF- $\alpha$-activated human endometrial stromal cells (HESCs). HESCs were cultured in the presence or absence of HEABG $(50 \mu \mathrm{g} / \mathrm{ml})$ for $1 \mathrm{~h}$, and then stimulated with TNF- $\alpha(10 \mathrm{ng} / \mathrm{ml})$ for $30 \mathrm{~min}$. The cells were then fractionated into cytosolic and nuclear extracts. The nuclear fractions were analyzed to determine the binding activity of NF- $\mathrm{\kappa B}$. Data plotted in the bar graphs are representative of 3 independent experiments with similar results. Results are expressed as the means \pm SD of triplicates. ${ }^{*} \mathrm{P}<0.01$ compared with the TNF- $\alpha$-treated group as determined by a t-test.

Effects of specific inhibitors of $N F-\kappa B$ and $A P-1$ on TNF- $\alpha$ induced ICAM-1 expression. To determine the role of $\mathrm{NF}-\kappa \mathrm{B}$ and AP-1 in TNF- $\alpha$-induced ICAM-1 expression in HESCs, the specific NF- $\kappa \mathrm{B}$ inhibitor, BAY 11-7085, and the specific AP-1 inhibitor, SR11302, were used. HESCs were incubated with either BAY 11-7085 (5 and $10 \mu \mathrm{M}$ ) or SR11302 (30 and $50 \mu \mathrm{M})$ for $1 \mathrm{~h}$ prior to stimulation with $10 \mathrm{ng} / \mathrm{ml} \mathrm{TNF-} \alpha$ for $15 \mathrm{~h}$, and the cell surface expression of ICAM-1 was analyzed by flow cytometric analysis. Of note, ICAM-1 expression in the TNF- $\alpha$-treated HESCs was completely abolished by the $\mathrm{NF}-\kappa \mathrm{B}$ inhibitor and partially inhibited by the AP-1 inhibitor in HESCs (Fig. 13). These data indicate that the effects of HEABG on the TNF- $\alpha$-induced ICAM-1 expression in HESCs are mediated through the $\mathrm{NF}-\kappa \mathrm{B}$ signal transduction pathway and partially through the AP-1 pathway.

\section{Discussion}

The results of the present study clearly indicate that the treatment of TNF- $\alpha$-activated HESCs with HEABG suppresses the expression of ICAM-1 and VCAM-1 at the mRNA and protein level, as well as cell proliferation, cell cycle progression and the secretion of IL- 6 . We demonstrated that TNF- $\alpha$, a central 


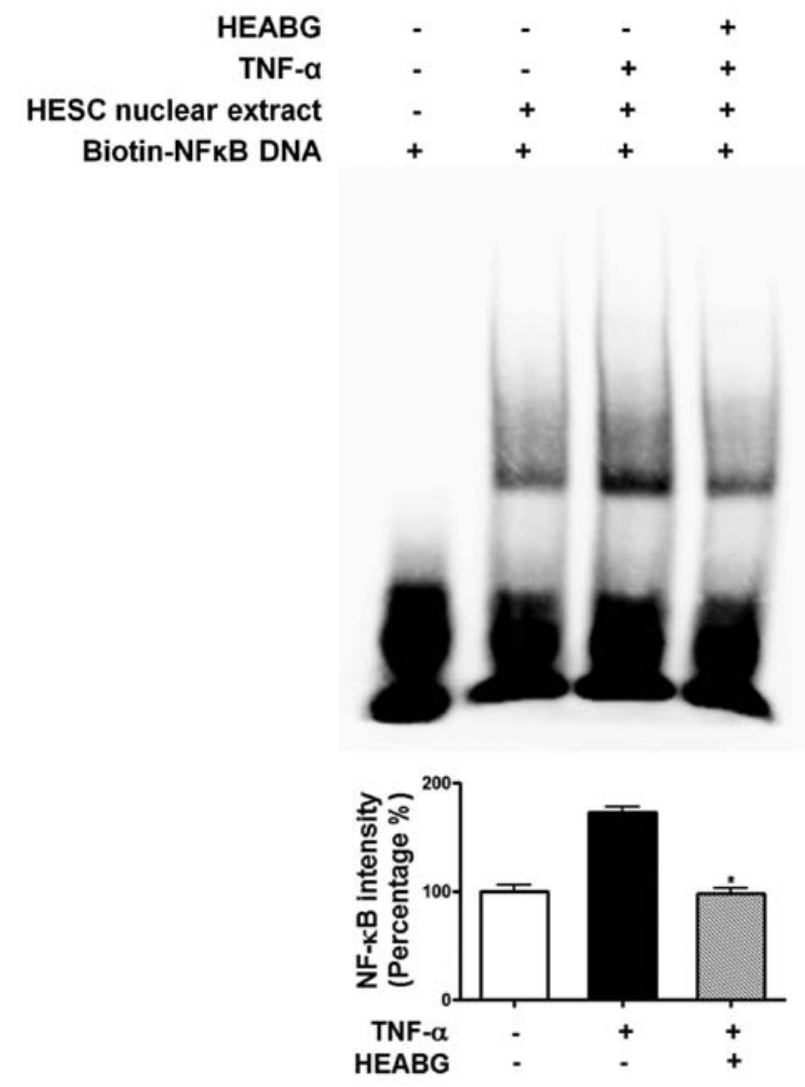

Figure 12. Electrophoretic mobility gel shift assay (EMSA) detection of the effect of hexane extract of aged black garlic (HEABG) on the binding activity of activator protein-1 (AP-1) with its target DNA in TNF- $\alpha$-activated human endometrial stromal cells (HESCs). HESCs were cultured in the presence or absence of HEABG $(50 \mathrm{~g} / \mathrm{ml})$ for $1 \mathrm{~h}$, and then stimulated with TNF- $\alpha(10 \mathrm{ng} / \mathrm{ml})$ for $30 \mathrm{~min}$. The cells were then fractionated into cytosolic and nuclear extracts. The nuclear fractions were analyzed to determine the binding activity of AP-1. Data plotted in the bar graphs are representative of 3 independent experiments with similar results. Results are expressed as the means \pm SD of triplicates. ${ }^{*} \mathrm{P}<0.01$ compared with the TNF- $\alpha$-treated group as determined by a t-test.

pro-inflammatory cytokine, markedly promotes the proliferation, cell cycle progression and the expression of ICAM-1, VCAM-1 and IL-6, induces the activation of the NF- $\mathrm{KB}$ and AP-1 transcription factors, and activates ERK and JNK and ERK, subgroups of the MAPK family in HESCs. These data suggest that TNF- $\alpha$ plays a crucial role in the pathogenesis of endometriosis through the marked enhancement of cell proliferation, as well as the expression of these critical inflammatory mediators in HESCs, as shown in Fig. 14. It has been shown that the abnormal production of TNF- $\alpha$ contributes to the pathophysiology of endometriosis (18).

The immune system plays an important role in the development of endometriosis $(2,3)$. Cell adhesion molecules, such as ICAM-1 and VCAM-1, play critical roles in various inflammatory and immunological functions, including cell-cell adhesion (4). ICAM-1 and VCAM-1 are strongly expressed in the HESCs of patients with endometriosis, suggesting that ICAM-1 and VCAM-1 play a role in the pathophysiology of this disease $(19,20)$. The pathophysiological importance of ICAM-1 expression in HESCs has attracted much attention. In particular, ICAM-1 expression may be associated with the defective functions of natural killer (NK) cells in endometriosis $(2,6,8)$. In patients with endometriosis, the elevated expression of ICAM-1 in HESCs gives rise to the shedding of soluble ICAM-1 (sICAM-1) from the cell surface to the peritoneal cavity, which subsequently binds to ICAM-1 receptors on NK cells (6). This interferes with the cytotoxic function of NK cells, and consequently, hinders them from killing ectopic endometrial cells in the peritoneal cavity $(2,6,21)$. This mechanism appears to form the basis for HESCs to escape immune surveillance, thus enabling the ultimate development of endometriosis. This hypothesis is further supported by findings that the endometrial release of sICAM-1 directly correlates with the number and score of endometriotic implants (22), and that women with endometriosis have elevated sICAM-1 levels in serum, demonstrating a correlation between the peritoneal and endometrial sICAM-1 release levels and the extent and severity of the disease $(6,23)$. These facts strongly underline the importance of the identification of agents that inhibit the expression of ICAM-1 for the development of effective inhibitors of the activity of HESCs. Thus, it is of significance that HEABG was found to have an effective and potent suppressive effect on the TNF- $\alpha$-induced upregulation of ICAM-1 and VCAM-1 expression in HESCs in the present study.

In agreement with the results of previous studies, we also demonstrate that TNF- $\alpha$ stimulation promotes the activation of NF- $\mathrm{KB}$ and AP-1, critical regulators of cell proliferation and inflammatory responses in HESCs, suggesting that these transcription factors are key factors in the pathogenesis of endometriosis $(3,14)$. The canonical pathway of NF- $\mathrm{kB}$ is activated in endometriotic lesions, and modulation of NF- $\kappa \mathrm{B}$ activity and the consequent cell responses, including proliferation, inflammation and adhesion are important in the development of endometriosis $(3,13,24,25)$. Thus, it is noteworthy that the present study demonstrated that HEABG significantly inhibits the TNF- $\alpha$-induced activation of NF- $\kappa$ B and AP-1 in HESCs. In particular, the involvement of the NF- $\mathrm{kB}$ and AP-1 pathways in the TNF- $\alpha$-induced ICAM-1 and VCAM-1 upregulation in HESCs was confirmed in this study, using specific NF- $\kappa B$ and AP-1 inhibitors. Taken together, these results suggest that HEABG exerts its inhibitory effect on ICAM-1 and VCAM-1 expression via the modulation of the activation and DNA binding activity of NF- $\mathrm{\kappa B}$ and AP-1.

The critical roles of pro-inflammatory cytokines, including IL-6 are well defined in the pathogenesis of endometriosis $(2,3)$. The activation of the NF-B and AP-1 transcription factors has been shown to play a crucial role in the enhanced expression of several pro-inflammatory cytokines, including IL-6 in HESCs (14). These findings along with the results of the present study suggest that HEABG blocks the TNF- $\alpha$-induced IL-6 expression in HESCs through the inhibition of the NF- $\kappa B$ and AP-1 transcription factors.

Cell proliferation is a fundamental process in the development of endometriotic lesions $(2,3)$. The MAPK cascade plays an important role in the signal transduction pathways that contribute to the regulation of complex cellular functions, including cell proliferation (26). There are at least 3 distinct and parallel MAPK pathways characterized by ERK, JNK and p38 MAPK. These MAPK signaling pathways are also present in endometrial cells, and MAPKs play pathophysiological roles in the development of endometriosis $(14,27)$. It has been shown 


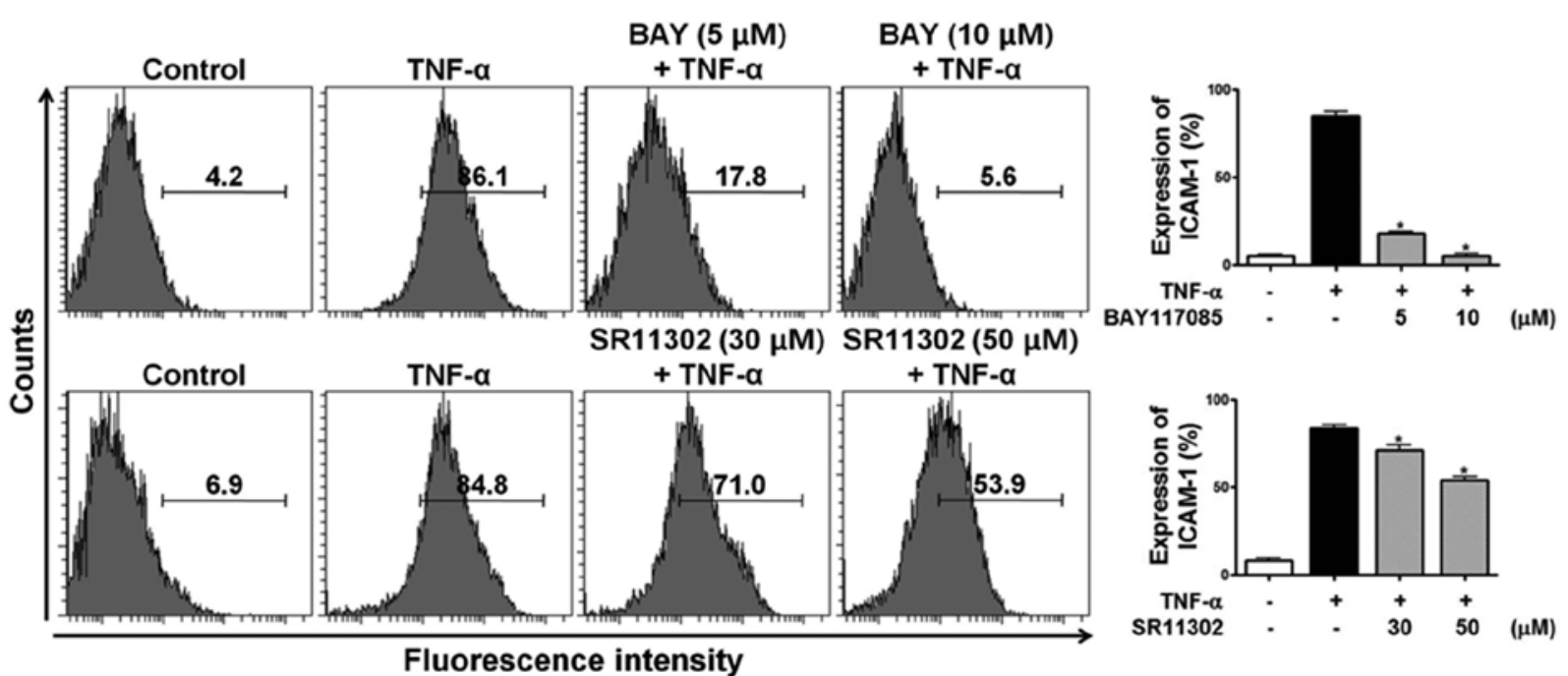

Figure 13. Effect of the specific inhibitors of NF- $\mathrm{KB}$ and activator protein-1 (AP-1) on the expression of intercellular adhesion molecule-1 (ICAM-1) in TNF- $\alpha$-activated human endometrial stromal cells (HESCs) detected by flow cytometric analysis. HESCs were pre-treated with BAY 11-7085 (specific NF- $\mathrm{kB}$ inhibitor) or SR11302 (specific AP-1 inhibitor) for $1 \mathrm{~h}$, and then stimulated with TNF- $\alpha$ (10 ng/ml) for $15 \mathrm{~h}$. Data in histograms are also plotted in bar graphs and expressed as mean \pm SD. Data are representative of 3 independent experiments with similar results. ${ }^{*}<0.05$ compared with the TNF- $\alpha$-treated group as determined by a t-test.

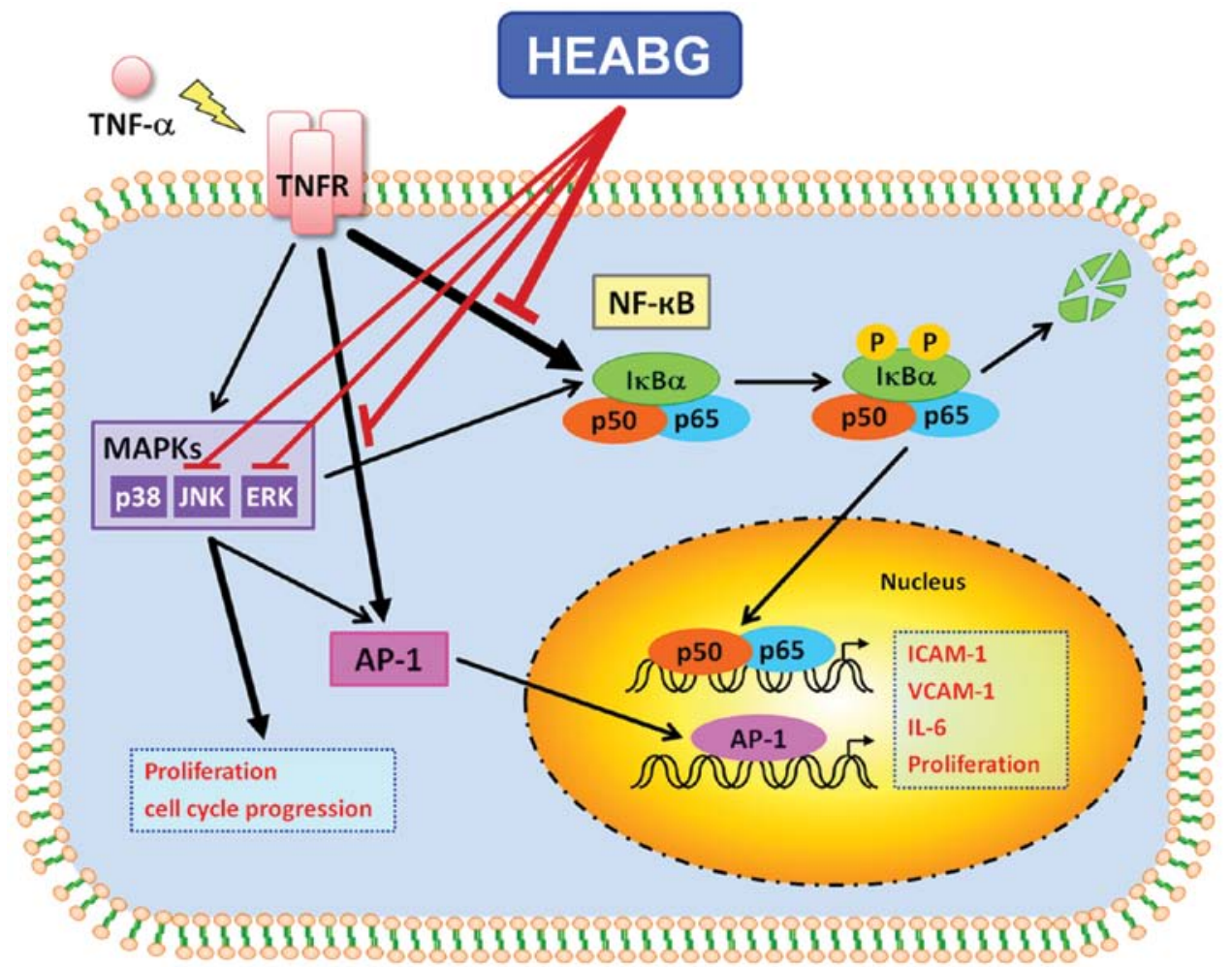

Figure 14. Proposed molecular mechanisms of action for hexane extract of aged black garlic (HEABG) in human endometrial stromal cells (HESCs). HEABG suppressed TNF- $\alpha$-induced intercellular adhesion molecule-1 (ICAM-1) and vascular cell adhesion molecule-1 (VCAM-1) expression,.. as well as IL-6 secretion by inhibiting the NF- $\mathrm{kB}$ and AP-1 pathways. In addition, HEABG suppressed the TNF- $\alpha$-promoted cell proliferation and cell cycle progression via through inhibition of the ERK and JNK signaling pathways.

that MAPK signaling pathways are abnormally activated in HESCs, and that MAPK acts upon the regulation of HESC proliferation $(28,29)$.

In agreement with previous studies, the present study clearly demonstrates that TNF- $\alpha$ induces the expression of all 3 types of MAPKs in HESCs $(14,27)$. Since we observed that
HEABG significantly inhibited the TNF- $\alpha$-induced activation of ERK and JNK in HESCs, we performed an experiment to define whether MAPKs are involved in the regulation of cell proliferation in TNF- $\alpha$-activated HESCs using their specific inhibitors. Of note, it was found that the inhibition of ERK and JNK hinders the proliferation and cell cycle progression 
of HESCs, suggesting that the TNF- $\alpha$-induced activation of the ERK/MAPK and JNK/MAPK signaling pathways plays a regulatory role in HESC proliferation. Moreover, HEABG markedly suppressed ERK/MAPK and JNK/MAPK activation in HESCs. Thus, our data indicate that HEABG effectively inhibits the TNF- $\alpha$-induced proliferation and cell cycle progression of HESCs by suppressing ERK/MAPK and JNK/MAPK activation.

Taken together, our data clearly indicate that HEABG may be effective in the prevention and treatment of endometriosis in humans. Of particular importance, our results indicate that HEABG, as a natural product, provides valuable insight into the development of novel and beneficial therapeutic modalities for combating endometriosis, since traditional hormone-based therapeutic agents have serious adverse effects when used for the long-term management of endometriosis.

\section{Acknowledgements}

This study was supported by the Bio-Scientific Research Grant funded by the Pusan National University (PNU, Bio-Scientific Research Grant) (PNU-2008-101-208).

\section{References}

1. Sampson JA: The development of the implantation theory for the origin of peritoneal endometriosis. Am J Obstet Gynecol 40: $549-557,1940$

2. Paul Dmowski W and Braun DP: Immunology of endometriosis. Best Pract Res Clin Obstet Gynaecol 18: 245-263, 2004.

3. Olovsson M: Immunological aspects of endometriosis: an update. Am J Reprod Immunol 66 (Suppl 1): 101-104, 2011.

4. Mousa SA: Cell adhesion molecules: potential therapeutic and diagnostic implications. Mol Biotechnol 38: 33-40, 2008.

5. Wu TC: The role of vascular cell adhesion molecule-1 in tumor immune evasion. Cancer Res 67: 6003-6006, 2007.

6. Somigliana E, Viganò P, Gaffuri B, Guarneri D, Busacca M and Vignali M: Human endometrial stromal cells as a source of soluble intercellular adhesion molecule (ICAM)-1 molecules. Hum Reprod 11: 1190-1194, 1996.

7. Tabibzadeh SS and Poubouridis D: Expression of leukocyte adhesion molecules in human endometrium. Am J Clin Pathol 93: 183-189, 1990.

8. Viganó P, Pardi R, Magri B, Busacca M, Di Blasio AM and Vignali M: Expression of intercellular adhesion molecule-1 (ICAM-1) on cultured human endometrial stromal cells and its role in the interaction with natural killers. Am J Reprod Immunol 32: 139-145, 1994

9. Viganò P, Gaffuri B, Somigliana E, Busacca M, Di Blasio AM and Vignali M: Expression of intercellular adhesion molecule (ICAM)-1 mRNA and protein is enhanced in endometriosis versus endometrial stromal cells in culture. Mol Hum Reprod 4: 1150-1156, 1998

10. Wu MH, Yang BC, Lee YC, Wu PL and Hsu CC: The differential expression of intercellular adhesion molecule-1 and regulation by interferon-gamma during the pathogenesis of endometriosis. Am J Reprod Immunol 51: 373-380, 2004.

11. Defrère $\mathrm{S}$, Donnez J, Moulin $\mathrm{P}$, Befahy $\mathrm{P}$, Gonzalez-Ramos $\mathrm{R}$, Lousse JC and Van Langendonckt A: Expression of intercellular adhesion molecule-1 and vascular cell adhesion molecule-1 in human endometrial stromal and epithelial cells is regulated by interferon-gamma but not iron. Gynecol Obstet Invest 65: $145-154,2008$
12. Braun DP, Ding J and Dmowski WP: Peritoneal fluid-mediated enhancement of eutopic and ectopic endometrial cell proliferation is dependent on tumor necrosis factor-alpha in women with endometriosis. Fertil Steril 78: 727-732, 2002.

13. González-Ramos R, Van Langendonckt A, Defrère S, Lousse JC, Colette S, Devoto L and Donnez J: Involvement of the nuclear factor- $\kappa \mathrm{B}$ pathway in the pathogenesis of endometriosis. Fertil Steril 94: 1985-1994, 2010.

14. Yamauchi N, Harada T, Taniguchi F, Yoshida S, Iwabe T and Terakawa N: Tumor necrosis factor-alpha induced the release of interleukin- 6 from endometriotic stromal cells by the nuclear factor-kappaB and mitogen-activated protein kinase pathways. Fertil Steril 82 (Suppl 3): 1023-1028, 2004.

15. Okamoto H, Cujec TP, Yamanaka H and Kamatani N: Molecular aspects of rheumatoid arthritis: role of transcription factors. FEBS J 275: 4463-4470, 2008.

16. Pittler MH and Ernst E: Clinical effectiveness of garlic (Allium sativum). Mol Nutr Food Res 51: 1382-1385, 2007.

17. Revised American Society for Reproductive Medicine classification of endometriosis: 1996. Fertil Steril 67: 817-821, 1997.

18. Pino M, Galleguillos C, Torres M, Sovino H, Fuentes A, Boric MA and Johnson MC: Association between MMP1 and MMP9 activities and ICAM-1 cleavage induced by tumor necrosis factor in stromal cell cultures from eutopic endometria of women with endometriosis. Reproduction 138: 837-847, 2009.

19. Prefumo F, Semino C, Melioli G and Venturini PL: A defective expression of ICAM-1 (CD54) on secretory endometrial cells is associated with endometriosis. Immunol Lett 80: 49-53, 2002.

20. Kyama CM, Overbergh L, Mihalyi A, Meuleman C, Mwenda JM, Mathieu C and D'Hooghe TM: Endometrial and peritoneal expression of aromatase, cytokines, and adhesion factors in women with endometriosis. Fertil Steril 89: 301-310, 2008.

21. Sikora J, Mielczarek-Palacz A and Kondera-Anasz Z: Role of natural killer cell activity in the pathogenesis of endometriosis. Curr Med Chem 18: 200-208, 2011.

22. Viganò P, Somigliana E, Gaffuri B, Santorsola R, Busacca M and Vignali M: Endometrial release of soluble intercellular adhesion molecule 1 and endometriosis: relationship to the extent of the disease. Obstet Gynecol 95: 115-118, 2000.

23. De Placido G, Alviggi C, Di Palma G, Carravetta C, Matarese G, Landino G and Racioppi L: Serum concentrations of soluble human leukocyte class I antigens and of the soluble intercellular adhesion molecule-1 in endometriosis: relationship with stage and non-pigmented peritoneal lesions. Hum Reprod 13: 3206-3210, 1998 .

24. González-Ramos R, Van Langendonckt A, Defrère S, Lousse JC, Mettlen M, Guillet A and Donnez J: Agents blocking the nuclear factor-kappaB pathway are effective inhibitors of endometriosis in an in vivo experimental model. Gynecol Obstet Invest 65: 174-186, 2008.

25. Nasu K, Nishida M, Ueda T, Yuge A, Takai N and Narahara H: Application of the nuclear factor-kappaB inhibitor BAY 11-7085 for the treatment of endometriosis: an in vitro study. Am J Physiol Endocrinol Metab 293: E16-E23, 2007.

26. Zhang $\mathrm{W}$ and Liu HT: MAPK signal pathways in the regulation of cell proliferation in mammalian cells. Cell Res 12: 9-18, 2002.

27. Wu MH, Wang CA, Lin CC, Chen LC, Chang WC and Tsai SJ: Distinct regulation of cyclooxygenase- 2 by interleukin-1beta in normal and endometriotic stromal cells. J Clin Endocrinol Metab 90: 286-295, 2005.

28. Hirota Y, Osuga Y, Hirata T, Harada M, Morimoto C, Yoshino O, Koga K, Yano T, Tsutsumi O and Taketani Y: Activation of protease-activated receptor 2 stimulates proliferation and interleukin (IL)-6 and IL-8 secretion of endometriotic stromal cells. Hum Reprod 20: 3547-3553, 2005.

29. Yotova IY, Quan P, Leditznig N, Beer U, Wenzl R and Tschugguel W: Abnormal activation of Ras/Raf/MAPK and RhoA/ROCKII signalling pathways in eutopic endometrial stromal cells of patients with endometriosis. Hum Reprod 26: 885-897, 2011. 